\title{
IMPROVING THE STRENGTH PERFORMANCE OF High VOLUME PERIWINKLE SHELl ASH BLENDED CEMENT CONCRETE WITH SODIUM NITRATE AS ACCELERATOR
}

\author{
Akaninyene A. Umoh ${ }^{1}$, Anthony O. Ujene ${ }^{2}$ \\ ${ }^{1,2}$ Building Department, Faculty of Environmental Studies, University of Uyo, Nigeria

\begin{abstract}
The objective of this study is to examine the effect of accelerator $\left(\mathrm{NaNO}_{3}\right)$ on the strength properties of High volume Periwinkle shell ash blended cement concrete. A mix ratio and water-binder ratio of 1:2:4 (cement: sand: gravel) and 0.60, respectively was used as the reference. The cement was then replaced with 30\% Periwinkle Shell Ash (PSA) by weight of cement. Sodium nitrate in the dosages of 1,2 , and $3 \%$ by weight of cement was added to the blended mixture of cement and PSA. The strength properties investigated were compressive and splitting tensile strength tested at 7, 14 and 28 days hydration. The results indicated that the compressive strength and the splitting tensile strength generally increases with curing age, and that sodium nitrate of up to $2 \%$ dosage greatly improved the strength performance of high volume PSA blended cement concrete over that of the reference. The study concluded that the inclusion of $2 \%$ sodium nitrate by weight of cement in the mixture could be considered the optimum dosage for the improvement of both compressive and splitting tensile strength of concrete incorporating up to $30 \%$ PSA content.
\end{abstract}

Keywords: compressive strength, periwinkle shell ash, tensile splitting strength, sodium nitrate, accelerator

\subsection{INTRODUCTION}

P

ERIWINKLES are marine snails belonging to the family of gastropoda found on land, in fresh water and in salt water. The species that is commonly found in the Niger Delta of the South - South region of Nigeria is termed Tympanotonus fuscatus and their habitat is mainly the brackish water creeks and mangrove swamps in the Niger Delta area at the inter-tidal zone, where they are found in clusters [1], [2]. They are dark and have thick elongated conical shape with narrow deep posterior canals and siphonal notches. A study indicated that there are about 40.3 tonnes of periwinkle per year being harvested from 35 mangrove communities of Delta and Rivers states [3].

When the edible part of periwinkle has been removed, the shell is being dump as waste. In communities' border with rivers, and in coastal regions of Nigeria where periwinkles are used as food, the shells posed environmental nuisance in terms of its unpleasant odour and unsightly appearance in open-dump sites.

The utilization of these shells by burning it under control condition to form ash, that is Periwinkle shell ash, and used as partial replacement of cement in concrete have been reported [4 - 6]. The assessment of the suitability of periwinkle shell ash (PSA) as partial replacement for ordinary Portland cement (OPC) in concrete [7] reported that the compressive strength of concrete specimens decreased as the percentage of PSA content increased. Similar studies [4,6] separately indicated that periwinkle shell ash 
with replacement level up to $10 \%$ in binary blended system in concrete have been reported to enhance concrete strength and durability. The use of PSA in concrete as reported by various researchers [6,8-9] pointed to the fact that only $10 \%$ replacement is effective in contributing to properties of the concrete. To enhance the performance of concrete in terms of its strength and durability, the use of admixtures, mineral or chemical admixture, as a component of the concrete material has been advocated.

According to National Ready Mixed Concrete Association, NRMCA [10], chemical admixtures are used to enhance the properties of concrete in the fresh and hardened state. These properties may be modified to increase compressive and flexural strength at all ages, decrease permeability and improve durability, inhibit corrosion, reduce shrinkage, accelerate or retard initial set, increase slump and workability, improve pumpability and finishability, increase cement efficiency, and improve the economy of the mixture.

Seven functional categories of chemical admixtures have been presented [11] to include retarding admixtures, accelerators, air-entraining agents, anti-freezing admixtures, anti-washout admixture, shrinkage reducing admixtures and high-range water reducers. This study is concerned with the use of accelerators. Accelerators speed up the setting and rate of strength gain [10] and thereby making the concrete stronger to resist damage from freezing in cold weather. Accelerators are also used in fast track construction requiring early form removal, opening to traffic or load application on structures. Many substances are known to act as accelerators for concrete and include Alkali Hydroxides, Silicates, Fluoro-Silicates, Calcium Formates, Calcium Nitrates, Sodium Nitrate, Calcium Thio Sulphates, Aluminium Chlorides, Potassium Carbonates, Sodium Chlorides and Calcium Chlorides. However, non- chloride admixtures are preferred as those containing chlorides are believed to accelerate corrosion of reinforcement.

The enhancement of concrete strength through the use of chemical admixtures in concrete has form the thrust of this study to improve the strength performance of concrete blended with high volume periwinkle shell ash up to $30 \%$ by weight of cement using sodium nitrate as an accelerator.

\subsection{METHODOLOGY}

Ordinary Portland cement (Unicem brand) was used which production conforms to the Nigeria Industrial Standard [12]. Erosion sand and granite chippings were used as fine and coarse aggregate, respectively. The sieve analysis of the erosion sand shows that it is in zone 2 ; while the coarse aggregate were predominantly of maximum aggregate size of $15 \mathrm{~mm}$ and both met the requirement of BS 882 [13]. Water used for the study was tap water while sodium nitrate $\left(\mathrm{NaNO}_{3}\right)$ was used as chemical admixture.

The periwinkle shells were obtained from Ishiet, Akwa Ibom State. The shells were calcined in a gas furnace at $600^{\circ} \mathrm{C}$ for 20-30 minutes and allowed in the furnace for 24 hours in order for it to cool. Thereafter, the ash was removed from the furnace, pound and sieved to particle sizes less than $75 \mu \mathrm{m}$ to obtain a fine ash. Chemical analysis conducted on the ash and as presented in Table 1shows that it has a higher content of calcium oxide $(\mathrm{CaO})$.

Table 1 Chemical Composition of Periwinkle Shell Ash

\begin{tabular}{cccccccccc}
\hline Elemental Oxide & $\mathrm{SiO}_{2}$ & $\mathrm{AL}_{2} \mathrm{O}_{3}$ & $\mathrm{Fe}_{2} \mathrm{O}_{3}$ & $\mathrm{CaO}$ & $\mathrm{MgO}$ & $\mathrm{SO}_{3}$ & $\mathrm{~K}_{2} \mathrm{O}$ & $\mathrm{Na}_{2} \mathrm{O}$ & $\mathrm{Mn}_{2} \mathrm{O}_{3}$ \\
\hline$\%$ & 27.20 & 6.42 & 4.64 & 52.10 & 0.82 & 0.26 & 0.25 & 0.26 & 0.14 \\
\hline
\end{tabular}

A mix ratio of 1:2:4 (cement: erosion sand: granite chipping) by weight and water-cement ratio of 0.60 was adopted as a reference mix. The cement constitute in the reference mix was replaced by weight with $30 \%$ quantity of periwinkle shell ash (PSA) and thereafter a Sodium nitrate $\left(\mathrm{NaNO}_{3}\right)$ of various dosages of 1, 2 and $3 \%$ by weight of cement were added to the $30 \%$ PSA blended cement concrete mix. 
The essence was to assess the effect of the $\mathrm{NaNO}_{3}$ on the strength performance of the concrete when compared to the reference and blended mixes.

Mixing was done manually using a shovel. The materials, cement or PSA or both, and aggregates were measured and mix dry until a uniform consistency was attained. The required water and sodium nitrate were measured and gradually added to the already mixed materials and thoroughly mixed until a workable mix was obtained. The wet mixture was then cast in $100 \mathrm{~mm}$ cube moulds and properly marked for identification prior to de-moulding after 24 hours of casting. The de-moulded concrete specimens were water cured for 7, 14 and 28 days corresponding to their testing ages.

The compressive strength test was carried out at testing ages of 7, 14 and 28 days using a compression test machine of capacity $1000 \mathrm{KN}$, and as specified by [14]. The compressive strength values were calculated from (1) thus:

$$
\mathrm{C}_{s}=\frac{\mathrm{P}}{\mathrm{A}} \text {. }
$$

Where $C_{s}$ is the Compressive strength of the concrete cube specimens in $\mathrm{N} / \mathrm{mm}^{2}, \mathrm{P}$ is the failure load in Newton, and $\mathrm{A}$ is the Area of the cube specimen in $\mathrm{mm}^{2}$

Tensile Splitting Strength test was equally carried out using concrete cube size $100 \mathrm{~mm}$. The test was done in line with [15]. The tensile splitting strength values were calculated from (2) thus:

$$
S_{\mathrm{T}}=\frac{2 P_{s}}{\pi l^{2}}
$$

Where $S_{T}$ is the tensile splitting in $N / \mathrm{mm}^{2}, \mathrm{P}_{\mathrm{s}}$ is the splitting load in Newton, and 1 is the length of each side of the specimen in $\mathrm{mm}$.

\subsection{RESULTS AND DISCUSSION}

\subsection{Compressive Strength}

The results of Compressive Strengths of PSA blended cement concrete tested at 7, 14 and 28 days are presented in Tables 2. The results indicated that the reference mix (that is mix with $0 \% \mathrm{NaNO}_{3}$ and $0 \%$ PSA content) had compressive strength values of $16.67 \mathrm{~N} / \mathrm{mm}^{2}, 21.12 \mathrm{~N} / \mathrm{mm}^{2}$ and $24.86 \mathrm{~N} / \mathrm{mm}^{2}$ at 7,14 and 28 days hydration, respectively; but with the replacement of cement with $30 \%$ PSA content, the strength was noticed to reduce to $14.60 \mathrm{~N} / \mathrm{mm}^{2}, 17.22 \mathrm{~N} / \mathrm{mm}^{2}$ and $20.66 \mathrm{~N} / \mathrm{mm}^{2}$ at 7,14 and 28 days, respectively. The value of $20.66 \mathrm{~N} / \mathrm{mm}^{2}$ recorded at 28 days by the mix containing $30 \%$ PSA is comparable to the values obtained by $[6,7]$ which used the same mix proportion of 1:2: 4 with $30 \%$ PSA content replacing cement in their investigation.

The inclusion of sodium nitrate in the mixture was noted to enhance the strength performance of the concrete. The strength increases with increase in the quantity of sodium nitrate up to $2 \%$ content and start to reduce at $3 \%$ dosage. Therefore a peak compressive strength was noted to attain with $2 \%$ dosage of $\mathrm{NaNO}_{3}$ at all the curing ages. This indicate that $2 \%$ sodium nitrate inclusion in the mixture could be considered the optimum dosage for the improvement of compressive strength of concrete incorporating up to $30 \%$ PSA content. 
Table 2 Compressive Strength of PSA blended cement concrete at Various Ages.

\begin{tabular}{ccccc}
\hline PSA (\% replacement of cement & $\mathrm{NaNO}_{3}(\%$ replacement of & \multicolumn{3}{c}{ Compressive Strength $\left(\mathrm{N} / \mathrm{mm}^{2}\right)$} \\
\cline { 3 - 5 } by weight) & cement by weight) & 7 Days & 14 Days & 28 Days \\
\hline 0 & 0 & 16.67 & 21.12 & 24.86 \\
30 & 0 & 14.60 & 17.22 & 20.86 \\
30 & 1 & 17.07 & 20.16 & 23.30 \\
30 & 2 & 19.83 & 22.50 & 25.10 \\
30 & 3 & 17.90 & 20.24 & 23.83 \\
\hline
\end{tabular}

\subsection{Tensile splitting strength}

The results of Tensile Splitting Strength as presented on Table 3 show that the reference mix recorded a tensile splitting strength that range between $1.67 \mathrm{~N} / \mathrm{mm}^{2}$ and $1.86 \mathrm{~N} / \mathrm{mm}^{2}$, and with the inclusion of $30 \%$ PSA in the mix the values were reduced to a range of $1.16 \mathrm{~N} / \mathrm{mm}^{2}$ and $1.63 \mathrm{~N} / \mathrm{mm}^{2}$ for the testing period of 7 to 28 days, respectively. These results agree with the findings [5] that tensile splitting strength increase with curing age and decreases as the percent weight of PSA increases from $15 \%$ to $30 \%$. The incorporation of $\mathrm{NaNO}_{3}$ up to $2 \%$ content was noticed to enhance the strength and thereafter the strength decline with increased in $\mathrm{NaNO}_{3}$ beyond $2 \%$ content.

Periwinkle shell ash blended cement concrete incorporating $2 \% \mathrm{NaNO}_{3}$ was observed to attain the highest tensile splitting strength at all the curing ages of 7, 14 and 28 days, this was closely followed by mix containing $30 \%$ PSA and $3 \% \mathrm{NaNO}_{3}$ especially at 28 days hydration. These findings indicate that sodium nitrate can be used to improve tensile strength performance of high volume periwinkle shell ash blended cement concrete.

Table 3 Tensile splitting Strength of PSA blended cement concrete at Various Ages.

\begin{tabular}{ccccc}
\hline PSA (\% replacement of cement & $\mathrm{NaNO}_{3}(\%$ replacement of & \multicolumn{3}{c}{ Tensile splitting Strength $\left(\mathrm{N} / \mathrm{mm}^{2}\right)$} \\
\cline { 3 - 5 } by weight) & 0 & 7 Days & 14 Days & 28 Days \\
\hline 0 & 0 & 1.67 & 1.72 & 1.86 \\
30 & 1 & 1.16 & 1.27 & 1.63 \\
30 & 2 & 1.36 & 1.44 & 1.80 \\
30 & 3 & 1.68 & 1.79 & 2.87 \\
30 & 3 & 1.60 & 1.66 & 2.76 \\
\hline
\end{tabular}

\subsection{CONCLUSIONS}

The study revealed that the inclusion of $\mathrm{NaNO}_{3}$ in high volume periwinkle shell ash blended cement concrete had contributed to the enhancement of the concrete compressive and splitting tensile strength performances. It was equally observed that there was continuity of performance with curing age and therefore, it is recommended that $\mathrm{NaNO}_{3}$ in the dosage of $2 \%$ of cement weight should be added to high volume periwinkle shell ash blended cement concrete mix to improve its performance.

\section{REFERENCES}

[1] M. A. O. Badmus, T. O. K. Audu, and B. U. Anyata, "Removal of Lead Ion from Industrial Wastewaters by Activated Carbon prepared from Periwinkle Shell (Typanotonus Fuscatus)," Turkish Journal of Engineering and Environmental Science, vol. 31, pp. 251-263, 2007.

[2] N. Jamabo, and A. Chinda, "Aspects of the Ecology of Tympanotonous fuscatus var fuscatus (Linnaeus,1758) in the Mangrove Swamps of the Upper Bonny River, Niger Delta, Nigeria," Current Research Journal of Biological Sciences, vol. 2, no. 1, pp. 42-47, 2010.

[3] P.C. Mmom, and S.B. Arokoya, "Mangrove Forest Depletion, Biodiversity Loss and Traditional Resources Management Practices in the Niger Delta, Nigeria," Research Journal of Applied Sciences, Engineering and Technology, vol. 2, no. 1, pp. 28-34, 2010. 
[4] A. A. Umoh, and K. O. Olusola, "Compressive strength and static modulus of elasticity of periwinkle shell ash blended cement concrete," International Journal of Sustainable Construction Engineering \& Technology, vol. 3, no. 2, pp. 45-55, 2012.

[5] A. A. Umoh, A. Olaniyi, A. J. Babafemi, and O. O. Femi, "Assessing the Mechanical Performance of Ternary Blended Cement Concrete Incorporating Periwinkle Shell and Bamboo Leaf Ashes," Civil and Environmental Research, vol. 3, no. 1, pp. 26-35, 2013.

[6] B. I. O. Dahunsi, and J. A. Bamisaye, "Use of Periwinkle Shell Ash (PSA) as Partial Replacement for Cement in Concrete, Proceedings the Nigerian Materials Congress and Meeting of Nigerian Materials Research Society, Akure, Nigeria, 2002, Nov.11 - 13, pp. 184-186.

[7] F. A. Olutoge, O. M. Okeyinka, and O. S. Olaniyan, "Assessment of the suitability of periwinkle shell ash (PSA) as partial replacement for ordinary Portland cement (OPC) in concrete," IJRRAS, vol. 10, no. 3, pp. 428-433, 2012.

[8] K. O. Olusola, and A. A. Umoh, "Strength Characteristics of Periwinkle Shell Ash Blended Cement Concrete," International Journal of Architecture, Engineering and Construction, vol. 1, no. 4, pp. 213-220, December 2012.

[9] B. R. Etuk, I. F. Etuk, and L. O. Asuquo, "Feasibility of Using Sea Shells Ash as Admixtures for Concrete," Journal of Environmental Science and Engineering A 1, pp. 121-127, 2012.

[10] National Ready Mixed Concrete Association, NRMCA, "Concrete in practice, what, why \& how?" NRMCA Publication No.173, 2001.

[11] P. Mihai, and R. B. Rosca, "Characteristics of concrete with admixtures," Gheorghe Asachi Technical University Bulletin 56, no. 58, 2008.

[12] NIS 444, Cement: Part 1-Compositiojn, Specification and Conformity Criteria for Common Cement, Abuja, Nigeria, 2003

[13] BS 882, Specification for aggregate from natural sources for concretes part II, London, British Standard Institution, 1992.

[14] BS EN 12390, Testing hardened Concrete: Compressive strength of test specimens, part 3, London, British Standard Institution, 2009.

[15] BS 1881, Testing hardened Concrete: Tensile Splitting strength of test specimens, part 117, London, British Standard Institution, 1983. 